\title{
TRANSNATIONAL TERRORISM: A THREAT TO GLOBAL SECURITY
}

LUCIE CALLÉJA

lucie.calleja@hotmail.fr

Ph.D. researcher at the Institute for Political Studies of Universidade Católica Portuguesa, Lisbon (Portugal). She is International Relations Executive Coordinator at Católica Global School of Law of Lisbon. She has been Board Advisor Trainee at the Institute for the Promotion of Latin America and the Caribbean (IPDAL) and Global Volunteer for Quality Education with AIESEC Salvador

\section{Abstract}

The beginning of the twenty-first century is characterised by the emergence of a new political landscape significantly influenced by globalisation. The rising interconnectivity that results from this phenomenon implies the need to redefine the concepts of international politics, strategies, threats, and security. In parallel, new technologies have enabled transnational threats to develop and come up as a primary concern for the great powers and global governance. Based on the analysis of previous works and relevant studies on the field (Brown, 2017; Bannelier-Christakis, 2016; Jones, Pascual, \& Stedman, 2009; Garcia, 2006), this essay explores the emergence of transnational terrorism and the expansion of religious extremism as major threats for states and individuals nowadays. While searching to answer the question of how to address terrorism and violent extremism, this article analyses diverse positions, measures, and consequences that have originated in a context of global insecurity. The increasing interdependency between internal and external security has called states to develop new strategies to maintain stability and order. The article emphasises the need to build partnerships and enhance collaboration at all levels to meet the challenges posed by transnational terrorism. In this context of growing insecurity, nations are urged to cooperate with different actors to protect their sovereignty and strengthen human security. Is the contemporary political landscape characterised by insecurity and disorder?

\section{Keywords}

Globalisation, Security, Threats, Transnational terrorism, Extremism, Global governance

\section{How to cite this article}

Calléja, Lucie (2021). Transnational terrorism: a threat to global security. Janus.net, e-journal of international relations. Vol12, No. 1, May-October 2021. Consulted [online] at date of last visit, https://doi.org/10.26619/1647-7251.12.1.1

Article received on January 23, 2020 and accepted for publication on September 28, 2020

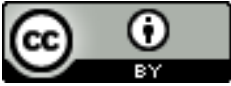




\title{
TRANSNATIONAL TERRORISM: A THREAT TO GLOBAL SECURITY
}

\author{
LUCIE CALLÉJA
}

\section{Introduction}

The unipolar world that emerged with the disappearance of the Soviet bloc and the affirmation of the United States as a superpower has increasingly been questioned after the tragic events of $9 / 11$. The phenomenon of globalisation has favoured the emergence of the concept of "multipolarity", shaping the balance of power between the different poles represented by states. Globalisation has blurred the tendencies and expectations for the future of international politics and of the new global order (Kaiser \& Rochefort, 2007). Although the decline of the American unipolarity, the rise of China and India as great powers, the persisting conflicts in the Middle East and Africa are observable facts, it remains difficult to approve a unique perspective about the evolution of international relations (de Senarclens, 2006). In this context, a multiplicity of potential interpretations and conclusions emerges. As Raymond Aron states, "the concepts and processes of research in international relations do not offer the certainty to anticipate the future" (Ibid, p.25). At most, they constitute interpretations that lighten up uncertain phenomenon and dynamics susceptible to affect the relationships between powers. "Great powers" often refer to a group of states who possess the resources and capabilities to project their influence on a global scale (Kaiser \& Rochefort, 2007). These states are usually characterised by the permanent members of the United Nations (China, France, Russia, the United Kingdom, and the United States of America), the European Union, and emergent regional powers such as Brazil, South Africa and India, the latter playing an increasingly important role on the global sphere (Ibid, 2007: 619). This interconnected framework has favoured the affirmation of a multipolar world in which the main players have been taking part in the international economic system (Zaluar \& Zeckhauser, 2002). Russia's power is rising back mainly due to its energy resources; Japan is the third world economy and exerts an active diplomacy worldwide; India emerges as a growing economy and a nuclear power; Brazil and South Africa arise as regional powers that start developing their influence on a global scale; China appears as a commercial and financial superpower; the European Union is an important actor in the world trade and constitutes the world's biggest aid provider; finally, the United States remains a significant power and influence, with a defense budget equal to the one of rest of the world (Kaiser \& Rochefort, 2007: 627).

In this globalised landscape, the emergence of new technologies has increased interactions between actors. Interdependencies and interconnections between states constitute necessary conditions for modernity, economic growth and development (Kaiser 
\& Rochefort, 2007). However, it appears fundamental to note that these conditions also open up new challenges and constraints for states. In fact, the nature of the primary threats for international security has taken a crucial turn. The "classic" inter-state wars of ideological or territorial nature have been replaced by intra-states conflicts, civil or ethnic wars, and common transnational threats such as terrorism (Ibid, 2007). The openness and wide volatility resulting from the globalisation have enabled these new forms of violence to develop. The increasing flows of merchandises, information, and humans, have significantly affected the notion of border (Ibid, 2007), becoming flexible and fluid zones of constant contacts and exchanges. Consequently, the beginning of our century is characterised by those threats - terrorism, organised crime, the proliferation of nuclear weapons, global warming, economic instabilities and disease - which overcome physical boundaries. In this context, states' security has taken a new sense and their integration in the international community has become essential to protect their interests (Garcia, 2006). In fact, these multiple threats have proven to go beyond the control of individual states and their transnational characteristic has created an inextricable interdependency between national and international security (Jones, Pascual \& Stedman, 2009). The classic dissuasion and deterrence methods systematically used in the past remain insufficient to protect against the new contemporary transnational threats. Indeed, mainly constituted by non-state actors, transnational threats are mobile, nonestablished in a specific territory, and often unpredictable (Kaiser \& Rochefort, 2007). The use of international networks to spread their ideas and reach a large number of people increases states' vulnerability and accordingly, "the greatest test of global leadership will be building partnerships and institutions for cooperation that can meet the challenge" of international insecurity and transnational threats (Jones, Pascual \& Stedman, 2009: 19).

Therefore, this essay focuses on transnational terrorism in the context of radical Islamism, its consequences on a global scale, and the methods used by states to protect their sovereignty in a context of global insecurity. Although the concept of "radical Islamism" remains ambiguous and does not bring a clear perception of the phenomenon, it is understood in this paper as a specific form of Islam, more political, that opposes the idea of modernisation, critical of the West, and that often involves violence (Mozaffari, 2007: 18). In this context, this research aims at answering the following research question: How do states confront the climate of global insecurity that arises from transnational terrorism? Other relevant research questions include: How does transnational terrorism affect the landscape of international relations? How do major powers deal with radical Islamism and the consequences it originates? Is the new international system characterised by a global disorder dominated by transnational terrorist organisations?

\section{Transnational Terrorism in a Globalised Context}

The context of globalisation and technological progress has enabled criminal and terrorist networks to increase and expand their influence worldwide. Former UN Secretary-General Kofi Annan speaks about the rise of an "uncivil society", which "may escape the control of the society of nations, and which constitutes a transnational threat to world governance" (Zaluar \& Zeckhauser, 2002: 25). Indeed, these groups are mainly non- 
state actors that mobilise the capabilities and resources to challenge the world's security and stability.

The concept of terrorism can be associated with a specific category of political discourse, using violence to reach political ends, and provoking a climate of insecurity and terror (Garcia, 2006: 347). Moreover, through direct and spectacular actions, terrorist organisations aim at generating social and psychological traumas as well as public resonance (Ibid, 2006:349). Following NATO's definition of terrorism, we understand the concept as:

"the unlawful use or threatened use of force or violence, instilling fear and terror, against individuals or property in an attempt to coerce or intimidate governments or societies, or to gain control over a population, to achieve political, religious or ideological objectives." (NATO, 2016).

The technological advances and interconnectivity that characterise our century have favoured the proliferation of criminal and terrorist networks on a global scale, exceeding national borders with their ideas and operations. Creating links with other non-state actors and organised networks of cultural and ideological nature, transnational terrorist organisations have developed new strategies and capabilities, becoming a significant threat of the twenty-first century. In this context, it appears important to analyse several characteristics of terrorist groups' strategies in order to better understand their global projection and impact.

Global technology is a major element through which transnational terrorist networks recruit supporters and members in every region of the world. These groups decentralise and develop local terrorist affiliations, enabling them to hold responsibility for operations that happen anywhere (Brown, 2017: 153). Indeed, the large mediatisation of terrorist attacks enables them to spread their message and reach a billion people around the world. For instance, the Islamic State of Iraq and the Levant (ISIL or ISIS) uses a large range of technologies (social media, videos posts, radio and TV channels, etc.) to claim responsibility during or after terror acts. After the 2019 Sri Lanka bombings causing about 350 deaths, the attackers posted a video pledging allegiance to ISIS' leader and declaring their responsibility for the attack (New York Times, 2019). Moreover, while mobilising the media, the theatrical feature of terrorist attacks publicises Islamist groups' operations and can contribute to their propaganda worldwide (Brown, 2017: 158). The strategy of decentralisation and the presence of smaller dispersed groups is based on the promotion of an ideology in which different people identify themselves and which permits them to exist on a global scale (Ibid, 2017). The sources of adhesion to these groups are often related to the anger associated with specific social and cultural issues, injustices, and the weakness of democratic institutions (Garcia, 2006: 351). The idea of a global Western coercion against the Islamic religion and the Muslim community spread by groups such as al-Qaeda, the Islamic State or Boko Haram, has expanded and motivated numerous terrorist assaults around the world.

More than for recruitment purposes, terrorist networks use technologies for internal organisation, coordination of actions, communication, and financing. Through chat tools, encrypted applications, adult's websites, they communicate their plans of actions, targets, photos, and instructions to undertake operations (Mates, 2001). In this regard, 
the Islamic State is said to be the "best capitalized on the new technologically driven landscape by remotely inspiring and directing attacks", as illustrated by the Curtis Culwell Center attack in Texas, U.S, in 2015, in which Twitter was used during the operation to direct the attackers (Harrison, 2019: 28).

Another core aspect of terrorist groups' strategies is the location chosen to undertake attacks. The objective is to generate terror and spread a specific message. The 2016 Nice attack (France) on the Bastille Day celebration, the Manchester Arena bombing (UK) in 2017 after Ariana Grande's concert, or the 2017 attack in La Rambla, in Barcelona, by a van killing several pedestrians, demonstrated the importance of targeting crowded locations to maximise the number of potential witnesses. The symbolic character of the locations chosen also appears to be important in terrorist groups' strategies. In fact, religious sites like synagogues, churches, or mosques are often targeted by shootings and suicide-bombings. In parallel, attacks in cities such as Paris or Brussels, representing globalised and touristic locations, increase the feeling of terror among people all around the world (Brown, 2017).

Moreover, although some jihadist groups act locally, consequences can be reflected on a larger scale (Ibid, 2017). In Nigeria, Boko Haram attacks villages, schools and individuals who do not respect the Sharia law and the principle of Salafism. Through kidnappings or suicide bombings, the Islamist group is responsible for the internal displacement of about 2,5 million people and the migration of nearly 250,000 Nigerian refugees to neighbouring countries of the Lake Chad region (UNHCR, 2019). These groups fight against local issues and individuals in specific regions, but the consequences of the insurgencies go beyond borders and involve a wide range of transnational and global actors. Moreover, as a large oil producer and a fast-growing economy, Nigeria constitutes a strategic actor in international relations. The United States Africa Command (USAFRICOM), established in 2007, has engaged in Nigeria and in the Sahel region to train military troops and fight against Boko Haram with the presence of about 1,000 military personnel in 2018 (Africa Faith \& Justice Network, 2018). In 2014, France launched "Operation Barkhane" and deployed 4,000 troops in the Sahel Region to provide material and intelligence aid against terrorism. This initiative intends to enable the countries of the region to counter terrorist threats independently and to strengthen their security (Permanent Mission of France to the UN in New York, 2019). China has also engaged in security cooperation with Nigeria, through the China-Africa Cooperative Partnership for Peace and Security, which aims at providing technical assistance on security operations across the African continent. Indeed, as Nigeria represents an important market for China and constitutes its third major African investment destination, China is very likely to increase its military involvement in the territory to protect its interests (Toogood, 2016). The context in Nigeria and the presence of the great powers in the Sahel region to assist the fight against transnational terrorist groups demonstrate the importance of such threats on a global scale. This case also characterises a situation in which the divergent economic and political interests of several major powers meet on a common path to combat violent extremism.

An additional important point is that transnational terrorist networks are often linked with other transnational threats, such as organised criminal organisations, especially for arms, money and drugs trafficking (Brown, 2017). In Western Africa and the Sahel region, alQaeda is deeply involved in criminal activities such as drug trafficking and money 
laundering. Engaging in activities with criminal networks enables the group to secure financial revenue to expand its influence and acquire weapons (Rousselier, 2011). Besides, unstable or failed states can favour the emergence of terrorist groups or be directly connected to the training and planning of operations, increasing insecurity among citizens and neighbour nations. Indeed, due to weak institutions and states' inability to exert power internally, terrorist groups can find opportunities to organise and develop themselves on territories where state's control is lacking or inexistent (Piazza, 2008). According to the Central Intelligence Agency (CIA), Al-Qaeda, the Islamic Jihad Union and the Islamic State of Iraq and ash-Sham-Khorasan, are examples of terrorist groups based in the Northern region of Afghanistan, which constitutes "a safe haven" to project their leadership (https://www.cia.gov, 2019). In the same line, the chaotic situation that devastated Syria from 2011 enabled the Islamic State to take over the control of several Syrian and Iraqi territories representing about 110,000 square kilometres and to bring close to 50,000 jihadists from abroad (U.S. Department of State, 2019). Internationally, Iran and Russia intervened to fight against ISIS and to support the Syrian government of Bashar al-Assad. On the other side, the U.S led a coalition composed of the Western states, the Sunni Arab states and Turkey, which intervened to defeat ISIS while asking for Bashar al-Assad's removal. However, due to the complexity of the intervention, the U.S-led coalition was often "constrained by conflicting aims and allegiances, doubts about the 'moderate' character of some rebel groups, and fears of being dragged deeper into the Syrian quagmire" (Bannelier-Christakis, 2016: 745).

\section{What Responses to the Global Disorder?}

In this complex and puzzling context, governments are urged to act in response and protect their citizens. However, due to the transnational characteristic of terrorist activities, it has been difficult for nations to determine the nature of their intervention (Brown, 2017). Several scholars have argued that "European counter-terrorism policies are more reactionary than effective because they follow the same pattern of government suppression of human rights in the name of security" (Ibid, 2017: 157). States have taken a broad range of internal measures, such as increasing the funding of government agencies working on anti-terrorist operations, denouncing extreme and radical opinions in schools, or mobilising intercultural events to counter the spread of ideologies carrying radicalisation and violence. However, national interventions and anti-terrorism legislation in Western societies have often been controversial and denounced for restricting liberties among citizens (Ibid, 2017). The American base in Guantanamo Bay, Cuba, represents a case of counter-terrorism measure that implied important human rights violations. G.W Bush established Guantanamo detention camp after the 11 September 2001 to detain and interrogate terrorists and individuals accused of committing war crimes. For many years, the international law framework was not respected, especially regarding the right to a fair trial for prisoners, the treatment and protection of detainees, considered by the U.S government as "unlawful combatants" who "could not enjoy the protection of international humanitarian law" (Guild \& Bigo, 2018: 34).

In another context, the more recent case of France constitutes another anti-terrorism measure that has been internationally contested. After a series of terror acts that took place in Paris in 2015, President Hollande declared the "state of emergency" across the 
French territory. The legislation consisted of the expansion of state surveillance to fight against terrorism and was extended several times until November 2017. However, several provisions and restrictions of the state of emergency were regarded by human rights experts as limiting the rights to privacy, freedom of expression, religious practice, peaceful assembly and association (Guild \& Bigo, 2018: 86). Taking as an example the closure of mosques under the state of emergency, the Special Rapporteur for CounterTerrorism and Human Rights, Ní Aoláin, stated: "It is clear that the French Muslim community has been the community primarily subject to exceptional measures both during the state of emergency and the new law in tandem with other counter-terrorism measures" (OHCHR, 2018). This case illustrates the large set of difficulties experienced by states in the fight against terrorism. Although governments may establish restrictions to guarantee public order, laws must respect and guarantee fundamental rights and civil liberties of all citizens.

In parallel, external measures have mainly consisted of developing greater cooperation between neighbour countries and state agencies to dismantle threats (Brown, 2017:154). Interventions abroad have been undertaken through military training, humanitarian aid and financial support, to prevent the expansion of terrorist groups in weak and failing states. The International Coalition led by the U.S. was established in 2014 to defeat ISIS in all fronts. Composed of more than eighty members ${ }^{1}$, the coalition is military active and united against the expansion of the Islamic State in several Iraqi and Syrian territories (https://theglobalcoalition.org). In March 2019, after four years of military and humanitarian intervention, all Syrian territories were liberated from ISIS' control. The Political Directors of the Global Coalition to Defeat ISIS declared in a joint statement that "today, Daesh/ISIS no longer controls territory and more than 7.7 million people have been freed from its control. [...] Nevertheless, Daesh/ISIS's territorial defeat does not represent the terrorist group's eradication or the end of the terrorist threat it poses" (U.S. Department of State, 2019). In this regard, the Coalition must continue to undertake its mission through military and political engagement.

In other cases, however, external interventions can lead to the support of undemocratic governments and have significant consequences on the international scene (Brown, 2017: 160). The "war on terror" engaged by the United States after 9/11, has implied the adoption of anti-terrorism laws by many authoritarian regimes and the provision of foreign aid for this purpose. However, in certain ways, this had justified civil liberties limitations and the use of violence in several undemocratic countries (Sahar, 2018). Egypt, as an ally of the U.S in counterterrorism, has committed human rights violations, torture of detainees, violence against people accused of being members of Islamist groups. Anti-terrorist laws are also used against civil society organisations, journalists, and human rights defenders, perceived as endangering national security. Nonetheless, since 1979, the United States has spent $\$ 41$ billion on security and counter-terrorism aid in Egypt (Ibid, 2018: 1606). Foreign assistance directed to authoritarian governments that violate citizens' fundamental liberties could, in return, play in favour of terrorist organisations and spread the image of Western aggressors supporting violent dictators (Brown, 2017: 160).

Including most of the European states, Canada, Australia, Japan, the Sunni Arab states, Turkey, the Community of Sahel-Saharan States, Interpol, NATO, etc. (https://theglobalcoalition.org/en/partners/). 
Consequently, the efforts made by states and other actors to counter terrorism manifest the importance of the terrorist threat worldwide and its consequences on global security. In response, the international community must address transnational threats through greater cooperation and common policies. States, decision-makers, international organisations, non-state actors and businesses, should build a cooperative strategy to enhance effective global governance in a context of growing insecurity (Zaluar \& Zeckhauser, 2002). In the case of the Sahel region, the Sahel Alliance was established in 2017 to strengthen cooperation between the great powers and the G5 Sahel countries (Burkina Faso, Chad, Mali, Mauritania, Niger) to face transnational threats such as terrorism and organised crime. The Alliance calls for the implementation of measures addressing populations' needs and ensuring regional security in vulnerable areas. The 12 donors $^{2}$ of the Sahel Alliance plan to donate about $€ 9$ billion to implement diverse projects in the region over the period 2018-2022 (diplomatie.gouv.fr, 2019). Such cooperative initiatives can potentially sustain stability and peace in vulnerable countries where transnational threats are predominant.

Although transnational terrorism constitutes a global threat, nations are differently concerned and affected. Due to the specific characteristics analysed in this essay, we observed that these transnational and mobile groups have a significant impact on states' legitimacy, sovereignty, and global security.

\section{Conclusion}

To conclude this essay, conflicts between Islamist groups and the West and its allies are very likely to continue influencing our century. The war in Iraq and Syria, the continuous recruitment of jihadists, and the expansion of a radical and violent Islam constitute elements that nourish transnational terrorism. In parallel, the relationships between the great powers constitute a complex issue within international relations. Although these nations have often defined common interests in countering terrorism, they also have strong divergent or opposed concerns, which can affect effective cooperation (Zaluar \& Zeckhauser, 2002). The main powers have a significant role in ensuring the stability and implementation of a global security community to counter transnational threats. First introduced by Karl Deutsch in 1957 and later rethought by Adler and Barnett (1998), the idea of "security communities" emphasises the need to build transnational identity and community at the international level to enable peaceful change, stability, and common security. In this regard, several scholars argue that liberal democracies should not have much difficulty in strengthening cooperation partnerships while protecting their freedom and national autonomy (Zaluar \& Zeckhauser, 2002: 16). Indeed, although policies against transnational threats may require a reinforcement of states' power, strong and stable democratic institutions will maintain a balance. In contrast, weak or undemocratic states might be unable to guarantee political and economic stability. Jones, Pascual and Stedman (2009) introduced the concept of "responsible sovereignty" referring to "the injunction that sovereignty entails obligations and duties to one's own citizens and to other sovereign states" (2009: 9). Indeed, the influences that result from states' decisions and actions go further their own borders and therefore, international security

2 France, Germany, the United Kingdom, Italy, Spain, the Netherlands, Luxembourg, Finland, the European Union, the African Development Bank, the United Nations Development Programme, and the World Bank. 
requires nations to project their sovereignty in collaboration with other players of the global order (Jones, Pascual \& Stedman, 2009).

It is essential to consider that transnational threats - terrorism, organised crime, the proliferation of nuclear weapons, climate change, economic instabilities, and infectious diseases - are often interconnected and their cumulative effect constitute a real danger for state's sovereignty (Jones, Pascual \& Stedman, 2009: 4). To address these security concerns and to preserve states' sovereignty, it appears essential to build cooperative agreements and alliances between the major nations, the United States, the European Union, China, Japan, Russia, other regional powers, such as India, Brazil, and South Africa, and with international institutions. Cooperative partnerships between investigation services and security agencies are also fundamental for countering transnational threats (Kaiser \& Rochefort, 2007: 622). An important issue that we could analyse further is the connections between transnational terrorism, organised crime and weapons of mass destruction (WMD). Nowadays, the international system of nonproliferation of nuclear weapons appears increasingly fragmented (Ibid, 2007). In addition to the five Security Council members, India, Pakistan, North Correa and Israel have acquired nuclear arms. Although until now the possession of WMD has been limited to states, it can quickly expand to transnational terrorist groups and provoke terrific consequences. This issue constitutes an important threat for all major powers that should be further studied.

Another current concern is the transmission of infectious diseases on a global scale and the inability of states to respond adequately. The global pandemic that arose in 2019 with the spread of COVID-19 has witnessed the vulnerability of international peace and security against such unpredictable threats. As the United Nations Under-SecretaryGeneral for Counter-Terrorism, Vladimir Voronkov, declared at the Virtual CounterTerrorism Week, "The COVID-19 pandemic has presented the international community with one of the greatest challenges since the creation of the United Nations 75 years ago - testing national resilience, international solidarity and multilateral cooperation" (United Nations, 2020). While the global concern is to fight the pandemic, terrorist organisations take advantage of the situation, and states must double their efforts to "strengthen multilateralism and international cooperation at all levels in order to 'build back better'" (United Nations, 2020). In fact, in a context of global insecurity, the international order depends on the coordination of common interests, the projection of responsible sovereignty, the existence of strong institutions, and the degree of cooperation between the major and emergent powers (Jones, Pascual \& Stedman, 2009: 15). The ability of states to mobilise the necessary resources and engage together will determine the international landscape of the twenty-first century.

\section{References}

Adler, Emanuel \& Barnett, Michael (1998). Security Communities. Cambridge: Cambridge University Press.

Africa Faith \& Justice Network (2018). U.S. Military Presence and Activity in Africa: Sahel Region [online]. [Accessed on November 9, 2019]. Available at: https://afjn.org/u-smilitary-presence-and-activity-in-africa-sahel-region/ 
Bannelier-Christakis, Karine (2016). Military Interventions against ISIL in Iraq, Syria and Libya, and the Legal Basis of Consent. Leiden Journal of International Law, Vol. 29, no. 3, 743-775. Cambridge University Press.

Brown, Katherine E. (2017). Transnational Terrorism. In McGlinchey (Ed.), International Relations (pp.152-162). Bristol: E-international Relations Publishing. [Accessed on September 28, 2020]. Available at: http://www.e-ir.info/wpcontent/uploads/2016/12/International-Relations-E-IR.pdf

de Senarclens, Pierre (2006). Théories et pratiques des relations internationales depuis la fin de la guerre froide. Politique étrangère, Vol hiver no. 4, 747-759. [Accessed on September 27, 2020]. Available at: https://doi.org/10.3917/pe.064.0747

Deutsch, Karl \& al. (1957). Political Community in the North Atlantic Area. Princeton: Princeton University Press.

France Diplomatie (2019). G5 Sahel Joint Force and the Sahel Alliance [online]. [Accessed on September 26, 2020]. Available at: https://www.diplomatie.gouv.fr/en/frenchforeign-policy/security-disarmament-and-non-proliferation/crises-and-conflicts/g5sahel-joint-force-and-the-sahel-alliance/

Garcia, Francisco P. (2006). As Ameaças Transnacionais e a Segurança dos Estados. Subsídios para o seu Estudo. Negócios Estrangeiros, no. 9.1, 339-374.

Gettleman, Jeffrey, Bastians, Dharisha, \& Mashal, Mujib (2019). ISIS Claims Sri Lanka Attacks, and President Vows Shakeup [online]. The New York Times. [Accessed on September 27, 2020]. Available at: https://www.nytimes.com/2019/04/23/world/asia/isis-sri-lanka-blasts.html

Guild, Elspeth \& Bigo, Didier (2018). Anti- \& counter- terrorism and human rights in Europe: 5 snapshots of current controversies. Queen Mary University of London, School of Law. [Accessed on September 28, 2020]. Available at: https://www.qmul.ac.uk/law/media/law/docs/events/QMUL-Report-July-2018.pdf

Harrison, Seth (2019). Evolving Tech, Evolving Terror [online]. Center for Strategic \& International Studies, Issue no. 15, 28-33. [Accessed on September 29, 2020]. Available at: https://www.csis.org/npfp/evolving-tech-evolving-terror

Jones, Bruce, Pascual, Carlos \& Stedman, Stephen (2009). Sovereignty's Last Best Chance. In Power and Responsibility: Building International Order in an Era of Transnational Threats (pp.3-20). Brookings Institution Press: Washington D.C.

Kaiser, Karl \& Rochefort, David (2007). Les grandes puissances au XXe siècle. Politique étrangère, Vol automne no. 3, 619-632. [Accessed on September 27, 2020]. Available at: https://doi.org/10.3917/pe.073.0619

Mates, Michael (2001). Technology and Terrorism (Draft Report). NATO Parliamentary Assembly, Sub-committee on the Proliferation of Military Technology. [Accessed on September 27, 2020]. Available at: https://www.tbmm.gov.tr/ul_kom/natopa/raporlar/bilim\%20ve\%20teknoloji/AU\%2012 1\%20STC\%20Terrorism.htm 
Mozaffari, Mehdi (2007). What is Islamism? History and Definition of a Concept. Totalitarian Movements and Political Religions, Vol. 8, No. 1:17-33. [Accessed on September 29, 2020]. Available at: DOI: $10.1080 / 14690760601121622$

NATO (2016). NATO's military concept for defence against terrorism [online]. [Accessed on September 27, 2020]. Available at: https://www.nato.int/cps/en/natohq/topics_69482.htm

Permanent Mission of France to the UN in New York (2019). France, a strategic partner of the Lake Chad basin countries [online]. [Accessed on September 28, 2020]. Available at: https://onu.delegfrance.org/France-a-strategic-partner-of-the-Lake-Chad-basincountries

Piazza, James A. (2008). Incubators of Terror: Do Failed and Failing States Promote Transnational Terrorism? International Studies Quarterly, Vol. 52, no. 3, 469-488. [Accessed on September 29, 2020]. Available at: http://www.jstor.org/stable/29734247

Rousselier, Jacques (2011). Terrorism in North Africa and the Sahel: Al-Qa'ida's Franchise or Freelance? Middle East Institute, Policy Brief no. 34. [Accessed on September 28, 2020]. Available at: https://www.themiddleeastjournal.org/sites/default/files/publications/Roussellier_0.pdf

Sahar, Aziz F. (2018). The Authoritarianization of U.S. Counterterrorism. Washington \& Lee Law Review, Vol. 75, Issue 3, no. 11, 1573-1635. [Accessed on September 26, 2020]. Available at: https://scholarlycommons.law.wlu.edu/wlulr/vol75/iss3/11

The Central Intelligence Agency (CIA). [Accessed on November 7, 2019]. Available at: https://www.cia.gov/library/publications/the-world-factbook/fields/397.html

The Global Coalition against Daesh (2019). [Accessed on November 8, 2019]. Available at: https://theglobalcoalition.org/en/

The United Nations Office of the High Commissioner for Human Rights (OHCHR) (2018). France: UN expert says new terrorism laws may undermine fundamental rights and freedoms. [Accessed on November 7, 2019]. Available at: https://www.ohchr.org/en/NewsEvents/Pages/DisplayNews.aspx?NewsID=23130\&Lang $\mathrm{ID}=\mathrm{E}$

The United Nations Refugee Agency (UNHCR) (2019). Nigeria emergency. [Accessed on November 6, 2019]. Available at: https://www.unhcr.org/nigeria-emergency.html

Toogood, Kimairis (2016). Understanding the Emerging Relationship between China and Africa: The Case of Nigeria (Policy Brief). [Accessed on November 7, 2019]. Available at: https://www.stimson.org/sites/default/files/file-

attachments/Understanding\%20the\%20Emerging\%20Relationship\%20Between\%20Chi na\%20and\%20Africa\%27s\%20China-\%20The\%20Case\%20of\%20Nigeria.pdf

U.S. Department of State (2019). The Global Coalition Post-Territorial Defeat of Daesh/ISIS: Paris Roadmap. Joint Statement by the Political Directors of the Global Coalition to Defeat ISIS. [Accessed on November 7, 2019]. Available at: https://www.state.gov/joint-statement-by-the-political-directors-of-the-globalcoalition-to-defeat-isis/ 
United Nations (2020). Partners Reaffirm Joint Commitment to Fighting Terrorism, Violent Extremism amid COVID-19, as Virtual Counter-Terrorism Week Concludes (Press Release). New York. [Accessed on September 29, 2020]. Available at: https://www.un.org/press/en/2020/pa30.doc.htm

Zaluar, Achilles. \& Zeckhauser, Richard (2002). The World of Transnational Threats (Working Paper). [Accessed on November 7, 2019]. Available at: https://sites.hks.harvard.edu/fs/rzeckhau/transnationalthreats.pdf 